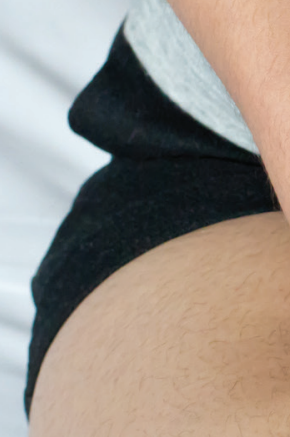

\title{
NITROSATIVE STATUS IN BENIGN EPITHELIAL OVARIAN CYSTIC TUMORS OF NONENDOMETRIOID ORIGIN
}

\section{M.A. LYSENKO}

postgraduate student of the Obstetrics and Gynecology Department № 1 , Odesa National Medical University, doctor at Surgical Department of minimally invasive methods of diagnosis and treatment of the University Hospital ONMedU ORCID: 0000-0002-5018-7921

\section{V.G. DUBININA}

MD, professor, head of the Oncology Department with a course of radiation diagnosis, therapy and radiation medicine, Odesa National Medical University

ORCID: 0000-0002-8405-4457

\section{O.M. NOSENKO}

$M D$, professor, 0bstetrics and Gynecology Department № 1, 0desa National Medical University

ORCID: 0000-0002-7089-2476

Contacts:

Mariana A. Lysenko

University Hospital ONMedU

Tenistaya str. 8, 65009, 0desa

Tel.: +38 (048) 7871441

+38 (048) 7706900

e-mail: maryana3004@gmail.com

\section{INTRODUCTION}

In the structure of cancer incidence special place are occupied benign tumors of the female genital organs. Ovarian tumors are in second place $(6.8 \%)$ from of all the female genital tumors. Benign forms are found in $75-80 \%$ of true ovarian tumors [7,9]. Despite the fairly detailed knowledge of ovarian tumors, causes of origin and benign tumors of ovarian cysts remain open. One of the most important areas of biomedical research in this field is to elucidate the molecular mechanisms that regulate cell proliferation and apoptosis. Violation of these processes leads to increased speed and reduced cell growth differentiation characteristic of tumor cells.

\section{ANALYSIS OF THE LITERATURE DATA AND STUDY OBJECTIVE}

Recently there has been an avalanche increase in the number of scientific publications on the study of the role of nitric oxide. Three American scientists Robert F. Furchgott, Louis J. Ignarro and Ferid Murad received the 1998 Nobel Prize. The goal of researchers was to study the so-called endothelial vascular relaxation factor (endothelium-derived relaxing factor). An unexpected and important discovery was the fact that this was a factor and nitric oxide (NO) [14].

NO is a biological messenger which is synthesized from L-arginine via nitric oxide synthase (NOS) [15]. Recent literature data show that NO, and NOS can modulate cancer-related events, including nitrozative, oxidative stress, apoptosis, cell cycle, angiogenesis, invasion and metastasis [21].

It were described several forms of NOS. For the vast localization in tissues they taken to provide neuronal (nNOS), endothelial (eNOS) and macrophage (macNOS). The first two types of enzymes are preferably constitutional, and the latter operates as inducible form of NOS (iNOS) [1], and in recent times has changed somewhat classification varieties of NO-synthase including distinguished:

1) NOS type 1 (constitutional-neuronal);

2) NOS type 2 (inducible NO-synthase);

3) NOS-3 type (endothelial-constitutional).

NOS type 1 is found mainly in the structures of the central and peripheral nervous system, constantly expressed under normal and pathological, is involved in the regulation of blood pressure. NOS type 2 (iNOS) is expressed in endothelial cells and macrophages in pathological processes, particularly during inflammation, is involved in the synthesis of pro-inflammatory cytokines tumor necrosis factor $a$, interleukin $1 \beta$. At the same time interleukins-4, 8, 10 , platelet-derived growth factor inhibiting iNOS and therefore the synthesis of NO. iNOS is expressed also in the heart at myocardial infarction, myocarditis, heart failure. iNOS was found in hepatocytes, chondrocytes. Constitutive endothelial NOS 3rd type involved in the regulation of vascular tone, expressed not only in vascular endothelium, but also in cardiomyocytes, platelets, endothelium lungs 
and kidneys. NOS constantly expressed under normal and pathological conditions [1].

Antiproliferative mechanism of action of NO was studied. Reducing the proliferative capacity of the cells under the influence of NO, possibly due to its ability to inactivate the effect of iron enzymes involved in the synthesis of adenosine triphosphate and DNA replication. It is believed that NO can enhance the cytotoxicity of free radicals, and NO-generating compounds that react free radical oxidation, can produce more cytotoxic compounds - peroxynitrite. Peroxynitrite, one of the most powerful oxidants, can directly or indirectly damage DNA and cause covalent modification of proteins in the cell and thus initsiyuyuvaty apoptosis [3]. NO has both cytotoxicity and cytostatic effect against microorganisms and malignant cells with synthesis of NO, which causes the NO-mediated apoptosis [10, 12].

At the same time, there are conflicting published data on the effect of increased cell proliferation under the influence of NO [8]. NO increases proliferation of normal human fibroblasts and aging. Increased NO production may lead to inhibition of apoptosis and increased cell viability lymphoma Nb2. These effects probably related to the antioxidant properties of NO, which due to its ability to bind to the membrane and intracellular iron complexes, inhibit decomposition of peroxides, intercept free radicals and put out the chain reaction of free radical oxidation. In addition, NO may activate intracellular processes in which enzymes from inactive soluble forms of transition to more active membrane [3].

If NO production there for a long period of time, the excessive production of NO may lead to mutations and ultimately to cancer $[16,20]$. In addition to increased metastatic potential of tumor cells by mutations in the DNA NO production by tumor cells promotes angiogenesis, essential process for tumor growth and support [11, 13].

Several studies have shown the important role of NO in ovarian physiology. It is shown that NO is synthesized locally ovaries and may play a role in the development of follicles, ovulation and luteal formation [18]. Data on changes in the content derived NO and NOS activity in benign ovarian tumor during virtually absent, which led to goals and objectives of our study.

Study aim - to explore the features of nitrozative status in benign epithelial cystic ovarian tumors of nonendometriod origin.

\section{MATERIALS AND METHODS}

The study involved 220 patients of reproductive age: 40 patients with follicular ovarian cysts (group F), 60 - with serous cystadenomas (group S), 60 - with mucinous cystadenomas (group M), 30 - with cystadenocarcinomas nonendometrioid origin (group C) and 30 conditionally healthy physical and gynecological patients in the control group (group K).

Criteria for inclusion in the study of reproductive age; histologically confirmed diagnosis of follicular cysts, serous cystadenomas, mucinous cystadenomas, cystadenocarcinomas nonendometrioid origin. Exclusion criteria: tilting breaks and cystic formations; previous hormonal drugs the day before surgery; endometriosis; metastasis of primary tumors of different origin; previous chemotherapy.
It were studied the stable NO metabolites in biological fluids such as blood and peripheral intracystic liquid. Aseptically peripheral blood was removed before the operation, intracystic fluid - during operation by aspiration. The collected fluid was centrifuged, stored at $t=-70^{\circ} \mathrm{C}$ to study. Intracystic samples of fluid from the blood impurities were excluded from the study.

To determine concentrations of stable metabolites of NO $\left(\mathrm{NO}_{2}^{-}+\mathrm{NO}_{3}^{-}=\mathrm{NO}_{x}\right)$ in biological fluids used the method by VA Metelskaya, NG Humanova [6]. This method is based on the recovery of $\mathrm{NO}_{3}^{-}$to $\mathrm{NO}_{2}^{-}$vanadium chloride (III), followed by determination of nitrite using Hrissa reagent (a solution of sulfanilamide and $\mathrm{N}$-naftyletylendiamine dihydrochloride in 30\% glacial acetic acid) as color image reagent (giving crimson color in the presence of NO liquids). To $0.2 \mathrm{ml}$ of the sample studied fill up $0.4 \mathrm{ml}$ of ethanol for deproteinizated, centrifuged for 20 minutes at 3000 rotations per minute. Next to each well microplate reader was added to $80 \mathrm{ml}$ of the supernatant, $80 \mathrm{ml}$ of vanadium chloride and $80 \mathrm{ml}$ reagent Hrissa. Measurements were made at immunosorbent analyzer Stat Fax 3200 (microplate reader) (Awareness technology Inc. Palm City, FL 34990, USA). Results are expressed in $\mathrm{mcmol} / \mathrm{l}$.

Determination of serum tumor markers CA 125, CA 19-9, HE-4 was carried out by immunochemical detection of e electrochemiluminescent method using standard reagents Roche Diagnostics (Switzerland) analyzer "Sobas ${ }^{\circledR} 6000$ analyzer series" (USA).

Operating specimens were fixed in $10 \%$ formalin before pouring in paraffin. Sections were stained with hematoxylin and eosin were reviewed and selected by a pathologist for immunohistochemical analysis. Selected deparafinized, rehydrated sections were heated in a microwave oven in $0.01 \mathrm{M}$ citrate buffer ( $\mathrm{pH}$ 6.0) for 30 minutes. The activity of endogenous peroxidase blocked with $3 \%$ hydrogen peroxide for 10 minutes, then washed with saline, phosphate buffered. Sections were incubated overnight at $4{ }^{\circ} \mathrm{C}$ with anti-iNOS rabbit polyclonal antibodies (NOS2 C-19: sc-649, Santa Cruz Biotechnology, Germany). As used conjugate avidin-biotin peroxidase solution (Dako Cytomation LSAB and system-HRP, Denmark). The signal was visualized using diaminobenzidine (Dako Cytomation Liquid DAB and substrate Chromogen System, Dako, Denmark). Sections were contrasted Harris hematoxylin, dehydratated, purified and studied morphometric. As a positive control was used a sample of skin with chronic granulomatous inflammation. The intensity of expression was assessed semiquantitative: the absence of expression - "-" with weak expression - " \pm ", with normal expression - " + " (corresponding to the control value), with increased expression (increased density of positive areas 30-50\%) - "++", while overexpression (increase positive half sections) - "+++" [17].

The resulting preparations were investigated using a light microscope.

Statistical analysis of the data was performed using Excel.

\section{RESULTS AND DISCUSSION}

Age of examined patients with serous cystadenomas has averaged $30.10 \pm 0.51$ years, with mucinous cystadenomas $30.17 \pm 0.47$, with follicular cysts $-30.43 \pm 0.57$, with cystadenocarcinomas $-31.57 \pm 31.57$, in control group $-30.00 \pm 0.45$ and probably did not differ between groups. 
The average diameter of cystic formations was the largest in the mucinous cystadenomas $(11.97 \pm 0.81 \mathrm{~cm})$ and cystadenocarcinomas $(9.90 \pm 0.94 \mathrm{~cm})$. In serous cystadenomas it amounted to $9.06 \pm 0.60 \mathrm{~cm}$, with follicular cysts $7.19 \pm 0.26 \mathrm{~cm}$.

Analysis of oncomarkers examined patients showed, as expected, their largest concentration in the presence cystadenocarcinomas (Table 1). In patients with follicular cysts, serous and mucinous cystadenomas the levels of oncomarkers were within reference values.

Study of $\mathrm{NO}_{\mathrm{x}}$ levels in biological fluids of examined patients revealed the likely reduction of serum neutral NO metabo- lites in the cystadenocarcinomas $(23.1 \pm 0.6 \mathrm{mmol} / \mathrm{l})$, serous (24.2 $\pm 0.3 \mathrm{mmol} / \mathrm{l})$ and mucinous $(23.9 \pm 0.4 \mathrm{mmol} / \mathrm{l})$ cystadenomas in comparison with follicular cysts $(25.2 \pm 0.3 \mathrm{mmol} / \mathrm{l})$ and control ( $26.2 \pm 0.2 \mathrm{mmol} / \mathrm{l})$ (Figure 1). Differences intracystic $\mathrm{NO}_{x}$ concentrations in mucinous, serous ystadenomas and follicular cysts were statistically significant, but small. At the same time the level of $\mathrm{NO}_{x}$ in intracystic contents of cystadenocarcinomas exceeded that of the follicular cysts in 1.96 times $(p<0.01)$, in serous cystadenomas in 1.99 times ( $p$ $<0.01)$ and mucinous cystadenomas in 1.79 times $(p<0,01)$ (Table 2, Figure 2 i 3).

\section{TABLE 1. LEVELS OF SERUM ONCOMARKERS IN EXAMINED PATIENTS}

\begin{tabular}{|c|c|c|c|c|c|c|}
\hline \multirow{2}{*}{ Formations' histostructure } & \multicolumn{2}{|c|}{ CA $125, \mathrm{U} / \mathrm{ml}$} & \multicolumn{2}{|c|}{ CA $19-9, \mathrm{U} / \mathrm{ml}$} & \multicolumn{2}{|c|}{ HE-4, pmol/l } \\
\hline & $M \pm m$ & $\min -\max$ & $M \pm m$ & $\min -\max$ & $M \pm m$ & $\min -\max$ \\
\hline Follicular cysts, $n=40$ & $7.32 \pm 1.13^{\mathrm{k}, \mathrm{m}, \mathrm{c}}$ & $3.20-29.35$ & $8.77 \pm 1.25^{\mathrm{k}, \mathrm{s}, \mathrm{m}, \mathrm{c}}$ & $12.56-32.31$ & $28.84 \pm 2.12^{k, s, m, c}$ & $15.33-38.62$ \\
\hline Mucinous cystadenomas, $\mathrm{n}=60$ & $17.13 \pm 1.10^{k, f, s, c}$ & $7.69-33.21$ & $28.82 \pm 1.90^{\mathrm{k}, \mathrm{f} s, \mathrm{c}}$ & $14.45-34.79$ & $43.05 \pm 2.06^{k, t, s, c}$ & $32.00-50.68$ \\
\hline Ovarian cystadenocarcinomas, $\mathrm{n}=30$ & $137.98 \pm 3.80^{k, f, s, m}$ & $32.78-677.52$ & $51.16 \pm 2.36^{\mathrm{k}, \mathrm{f}, \mathrm{s}, \mathrm{m}}$ & $26.61-92.33$ & $101.16 \pm 3.32^{k, t, f, m}$ & $78.35-198.11$ \\
\hline Normative data & \multicolumn{2}{|c|}{$0-35$} & \multicolumn{2}{|c|}{$0-37$} & \multicolumn{2}{|c|}{$0-70$} \\
\hline
\end{tabular}

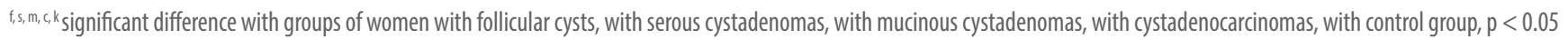

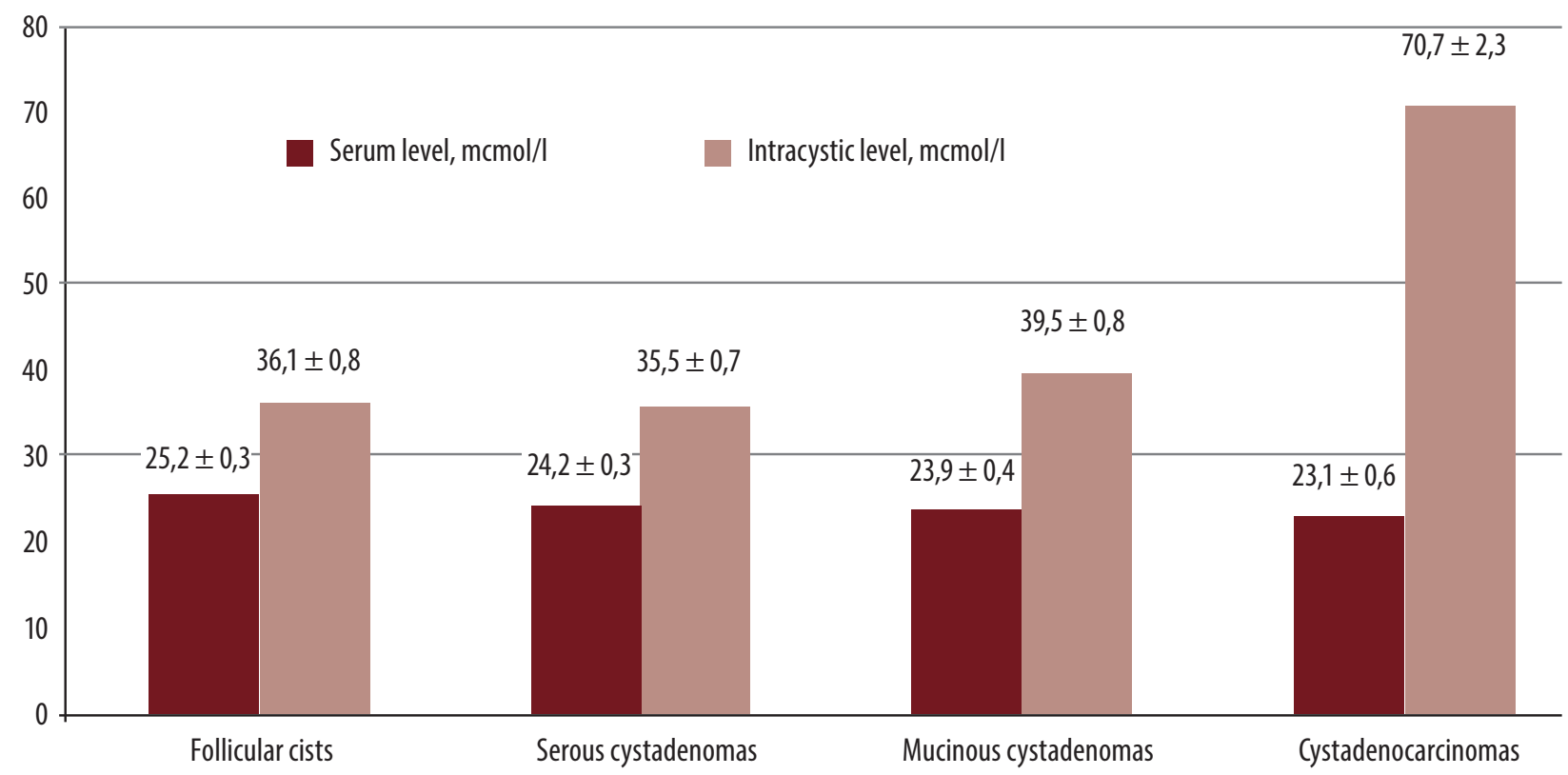

FIGURE 1. THE AVERAGE NO ${ }_{x}$ LEVEL IN BIOLOGICAL FLUIDS OF PATIENTS (mMol/I)

TABLE 2. THE INTENSITY OF INOS IMMUNOHISTOCHEMICAL STAINING IN THE WALLS REMOVED FORMATIONS, n (\%)

\begin{tabular}{|c|c|c|}
\hline Formations' histostructure & The weak intensity of iNOS expression $(+/-$ or +$)$ & Increased intensity of iNOS expression $(++$ or +++$)$ \\
\hline Follicular cysts, $n=40$ & $28(70.00)^{c}$ & $12(30.00)^{c}$ \\
\hline Serous cystadenomas, $n=60$ & $43(71.67)^{c}$ & $17(28.33)^{c}$ \\
\hline Ovarian cystadenocarcinomas, $n=30$ & $3(10.00)^{f, s, m}$ & $27(90.00)^{\mathrm{f}, \mathrm{s,m}}$ \\
\hline
\end{tabular}

$\mathrm{f}, \mathrm{s,m}, \mathrm{c}, \mathrm{k}$ significant difference with groups of women with follicular cysts, with serous cystadenomas, with mucinous cystadenomas, with cystadenocarcinomas, with control group, $\mathrm{p}<0.05$ 


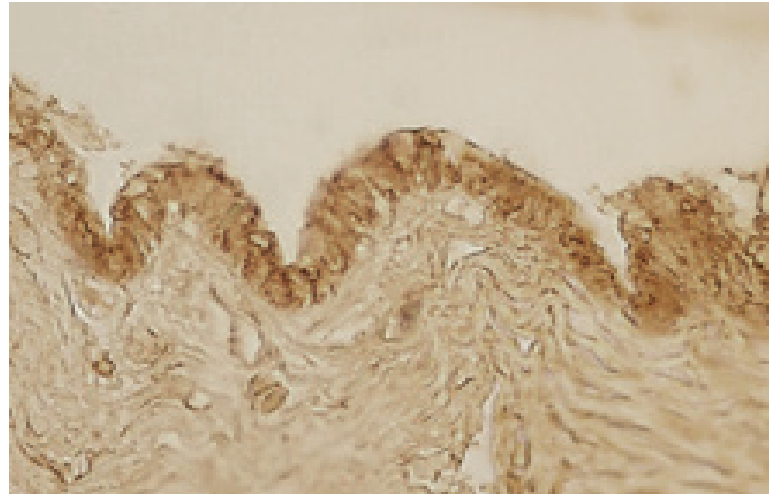

FIGURE 2. INCREASED INTENSITY OF IMMUNOHISTOCHEMICAL COLORING OF INOS IN THE MUCINOUS CYSTADENOMA WALL. IMMUNOHISTOCHEMISTRY WITH PAT TO NOS TYPE $2, \times 200$

\section{CONCLUSIONS}

1. NO and iNOS effect of on hyperproliferation processes in the ovaries is twofold.

2. NO and iNOS reducing expression and their minor activity may impact on the cystic tumor formation and benign tumor formation in the ovaries.

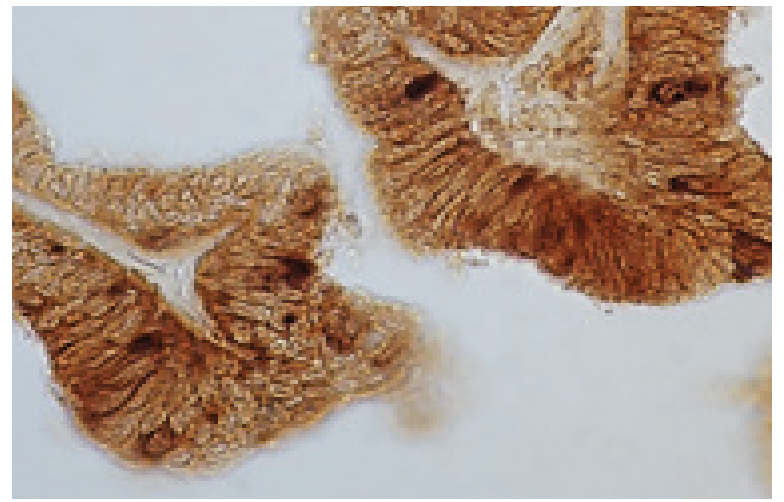

FIGURE 3. iNOS OVEREXPRESSION IN THE HIGH-GRADE CYSTADENOCARCINOMA WALL. IMMUNOHISTOCHEMISTRY WITH PAT TO NOS TYPE $2, \times 300$

3. NO overexpression and iNOS increased activity associated with the malignancy processes in cystic formations of epithelial origin.

\section{REFERENCES/ЛІTEPATYPA}

1. Активация липопероксидации как ведущий патогенетический фактор развития типовых патологических процессов и заболеваний различной этиологии [Электронный ресурс]. - Издательство «Академия Естествознания», 2012. Режим доступа: [http://www.rae.ru/ monographs/178].

Activation of lipid peroxidation as a leading pathogenetic factor of typical pathological processes and diseases of different etiologies [Online]. Publishing "Academy of Natural Science" (2012). Avialable from: [http://www.rae.ru/monographs/178], last accessed Feb 25, 2016.

2. Дубинина, В.Г.

Саногенез у больных с платинорефрактерным раком яичников / В.Г. Дубинина, А.И. Рыбин, О.В. Кузнецова //

Вісник морської медицини. - 2014. - № 1-2. - С. 51-57.

Dubinina, V.G., Rybin, A.I., Kuznetsova, 0.V.

"Sanogenesis in patients with the platynorefractory ovarian cancer." Journal of Maritime Medicine 1.2 (2014): 51-57.

3. Какурина, Г.В.

Роль оксида азота в регулировании пролиферации и апоптоза опухолевых клеток : автореф. дис. ... канд. мед. наук : 14.00.14, 14.00.16 / Г.В. Какурина. - Томск, 2004. - 19 Kakurina, G.V.

Nitric oxide role of in the regulation of apoptosis and proliferation in tumor cells. Thesis abstract for the PhD degree, specializations 14.00.14, 14.00.16. Tomsk (2004): 19 p.

4. Комаревцева, И.А.

Уровень оксида азота в тканях, сыворотке крови, мононуклеарных и мезенхимальных стволовых клетках / И.А. Комаревцева, Е.А. Орлова, М.В. Тарасова и др. // Український журнал клінічної та лабораторної медицини. 2009. - T. 4, № 4. - C. 133-137.

Komarevtseva, I.A., Orlova, E.A., Tarasova, M.V., et al. "Nitric oxide level in tissues, serum, mononuclear and mesenchymal stem cells." Ukrainian Journal of Clinical and Laboratory Medicine 4.4 (2009): 133-137.

5. Маркеры воспаления и окислительного стресса [Электронный ресурс]

Режим доступа: [http://www.biochemmack.ru/upload/uf/59e/ 59e74cd08ad31f9c72ede8466c1b211a.pdf].

Markers of inflammation and oxidative stress [0nline]. Avialable from: [http://www.biochemmack.ru/upload/ uf/59e/59e74cd08ad31f9c72ede 8466c1b211a.pdf], last accessed Feb 25, 2016.
6. Метельская, В.А.

Скрининг-метод определения уровня метаболитов оксида азота в сыворотке / В.А. Метельская, Н.Г. Гуманова // Клиническая лабораторная диагностика. - 2005. - № 6. C. 15-18.

Metelskaya, V.A., Gumanova, N.G.

"Screening method for determining the nitric oxide level in serum metabolites." Clinical Laboratory Diagnostics 6 (2005): 15-8.

7. Носенко, 0.М.

Доброякісні кістозні утворення яєчників: епідеміологія, патогенез, діагностика та відновлення репродуктивного здоров'я : автореф. дис. ... д. мед. наук : 14.01 .01 /

0.М. Носенко. - Київ, 2008. - 42 с.

Nosenko, 0.M.

Benign ovary cystic formation: epidemiology, pathogenesis, diagnosis and recovery of reproductive health. Thesis abstract for the MD degree, specialization 14.01.01. Kyiv (2008): 42 p.

8. Раевская, Т.А.

Доноры оксида азота как модуляторы лекарственной резистентности опухолей : автореф. дисс. ... канд. биол. наук : 03.00.02 / Т.А. Раевская. - Черноголовка, 2006. - 123 с. Raevskaya, T.A.

Nitric oxide donors as modulators of tumors drug resistance. Thesis abstract for the PhD degree, specialization 03.00.02. Chernogolovka (2006): 123 p.

\section{9. Серебренникова, К.Г.}

Современные представления об этиологии и патогенезе опухолевидных образований и доброкачественных опухолей яичников / К.Г. Серебренникова, Е.П. Кузнецова // Саратовский научно-медицинский журнал. - 2010. - Т. 6 № 3. - C. 552-558.

Serebrennikova, K.G., Kuznetsova, E.P.

"Current concepts of etiology and pathogenesis of tumor-like formations and benign ovarian tumors." Saratov Journal of Medical Science 6.3 (2010): 552-8.

10. Akaike, T., Maeda, H.

"Nitric oxide and virus infection." Immunology 101.3 (2000): $300-8$

11. Andrade, S.P., Hart, I.R., Piper, P.J.

"Inhibitors of nitric oxide synthase selectively reduce flow in tumour-associated neovasculature." British Journal of Pharmacology 107.4 (1992): 1092-5.
12. Chhatwal, V.J.S., Moochhala, S.M., Chan, S.T.F., Ngoi, S.S "Nitric oxide and cancer." Medical Hypotheses 46.1 (1996): 21-4.

13. Chu, S.C., Marks-Konczalik, J., Wu, H.-P., Banks, T.C., Moss, J. "Analysis of the cytokine-stimulated human inducible nitric oxide synthase (iNOS) gene: characterization of differences between human and mouse iNOS promoters." Biochemical and Biophysical Research Communications 248.3 (1998): 871-8.

14. Furchgott, R.F.

"An historical survey and prospects of research on EDRF." Nihon Heikatsukin Gakkai Zasshi 23.6 (1987): 435-40.

15. Nomelini, R.S., de Abreu Ribeiro, L.C., Tavares-Murta, B.M. et al.

"Production of Nitric Oxide and Expression of Inducible Nitric Oxide Synthase in Ovarian Cystic Tumors." Mediators Inflamm (2008).

DOI: $10.1155 / 2008 / 186584$

16. Ohshima, H., Bartsch, $H$.

"Chronic infections and inflammatory processes as cancer risk factors: possible role of nitric oxide in carcinogenesis." Mutation Research / Fundamental and Molecular Mechanisms of Mutagenesis 305.2 (1994): 253-64.

17. Özel, E., Peştereli, H.E., Şimşek, T., Erdoğan, G., Karaveli, F.Ş. "Expression of cyclooxygenase-2 and inducible nitric oxide synthase in ovarian surface epithelial carcinomas: is there any correlation with angiogenesis or clinicopathologic parameters?" International Journal of Gynecological Cancer 16.2 (2006): 549-55.

18. Reis, F.M., Faletti, A., Luisi, S., Bifulco, G., et al.

"High concentrations of inhibin A and inhibin B in ovarian serous cystadenoma: relationship with oestradiol and nitric oxide metabolites." Mol Hum Reprod 6.12 (2000): 1079-83.

19. Rieder, J., Marth, C., Totzke, G., Smolny, M., et al. "Different patterns of inducible nitric oxide synthase gene expression in ovarian carcinoma cell lines." Anticancer Research 20.5 (2000): 3251-8.

20. Shi, Q., Xiong, Q., Wang, B., Le, X., Khan, N.A., Xie, K. "Influence of nitric oxide synthase II gene disruption on tumor growth and metastasis." Cancer Research 60.10 (2000): 2579-83. 21. Yang, G.Y., Taboada, S., Liao, J.

"Induced nitric oxide synthase as a major player in the oncogenic transformation of inflamed tissue." Methods Mol Biol 512 (2009): 119-56.

DOI: $10.1007 / 978-1-60327-530-9 \_8$ 


\section{NITROSATIVE STATUS IN BENIGN EPITHELIAL CYSTIC OVARIAN TUMORS OF NONENDOMETRIOID ORIGIN}

M.A. Lysenko, postgraduate student of the Obstetrics and Gynecology Department № 1, 0desa National Medical University , doctor at Surgical Department of minimally invasive methods of diagnosis and treatment (University Hospital ONMedU)

V.G. Dubinina, MD, professor, head of the Oncology Department with a course of radiation diagnosis, therapy and radiation medicine, Odesa National Medical University

0.M. Nosenko, MD, professor, Obstetrics and Gynecology Department № 1, 0desa National Medical University

Ovarian tumors are in second place (6-8\%) from of all the female genital tumors. Benign forms are found in $75-80 \%$ of true ovarian tumors. Despite the fairly detailed knowledge of ovarian tumors, causes of origin and benign tumors of ovarian cysts remain open. Several studies have shown the important role of N0 in ovarian physiology. It was shown that N0 is synthesized locally ovaries and may play a role in the development of follicles, ovulation and luteal formation. Data on changes in the content NO derived and NOS activity in benign ovarian tumor are absent.

The aim of the study was to investigate the characteristics of nitrosative status of benign epithelial cystic ovarian tumors of nonendometrioid origin. 220 patients of reproductive age were examined: 40 patients with ovarian follicular cysts, 60 - with serous cystadenomas, 60 - with mucinous cystadenomas, 30 - with cystadenocarcinomas of nonendometrioidnogo origin, 30 patients consist control group. NO level of in the serum and in intracystic content, iNOS imunoreactivity in the walls of the remote masses were investigated.

Study of $\mathrm{NO}_{x}$ levels in biological fluids revealed the likely reduction of serum neutral NO metabolites in the cystadenocarcinomas, serous and mucinous cystadenomas in comparison with follicular cysts and control. Differences of intracystic $\mathrm{NO}_{\mathrm{x}}$ concentrations in mucinous, serous cystadenomas and follicular cysts was small.

Immunohistochemical study of iNOS expression showed its small level in follicular cysts and benign cystadenomas, but high level in cystadenocarcinomas.

Thus, $\mathrm{NO}$ and iNOS effect of on hyperproliferation processes in the ovaries is twofold. NO and iNOS reducing expression and their minor activity may impact on the cystic tumor formation and benign tumor formation in the ovaries. NO overexpression and iNOS increased activity associated with the malignancy processes in cystic formations of epithelial origin.

Keywords: nitrosative status, cystic ovarian tumors of nonendometrioid origin, $\mathrm{NO}_{\mathrm{x}^{\prime}}$ iNOS, immunohistochemistry.

\section{НІТРОЗАТИВНИЙ СТАТУС ПРИ ДОБРОЯКІСНИХ ЕПІТЕЛІАЛЬНИХ КІСТОЗНИХ ПУХЛИНАХ ЯЕЧНИКІВ НЕЕНДОМЕТРІОЇДНОГО ПОХОДЖЕННЯ}

М.А. Лисенко, аспірант кафедри акушерства та гінекології № 10 деського НМУ, лікар хірургічного відділення малоінвазивних методів діагностики та лікування Університетської клініки Одеського НМУ

В.Г. Дубініна, д. мед. н., професор, зав. кафедрою онкології з курсом променевої діагностики, терапії та радіаційної медицини Одеського Нму

0.М. Носенко, д. мед. н., професор кафедри акушерства та гінекології № 10 деського НМУ

Серед усіх пухлин жіночих статевих органів пухлини яєчників займають друге місце (6-8\%) за частотою. Доброякісні форми зустрічаються в 75-80\% всіх справжніх пухлин яєчників. Незважаючи на досить докладну вивченість новоутворень яєчників, причини походження їхніх доброякісних пухлин і кіст залишаються нез'ясованими.

Декілька досліджень виявили важливу роль оксиду азоту (N) в оваріальній фізіології. Показано, що яєчники локально синтезують N, і він може відігравати роль в процесах розвитку фолікулів, овуляції та лютеїнового формування. Дані про зміну рівня похідних оксиду азоту та активності синтази оксиду азоту (NOS) при доброякісному пухлинному процесі в яєчниках практично відсутні.

Метою проведеного дослідження було вивчення особливостей нітрозативного статусу при доброякісних епітеліальних кістозних пухлинах яєчників неендометріоїдного походження.

0бстежено 220 пацієнток репродуктивного віку: 40 пацієнток із фолікулярними кістами яєчників, 60 - із серозними цистаденомами, 60 - із муцинозними цистаденомами , 30 - із цистаденокарциномами неендометріӧ̈дного походження, а також 30 пацієнток контрольної групи. Досліджений вміст N0 в сироватці крові, інтракістозному вмісті, імунореактивність індуцибельної форми NOS (iNOS) у стінках видалених утворень.

Вивчення рівнів N0 в біологічних рідинах пацієнток виявило вірогідне зниження вмісту сироваткових нейтральних метаболітів N0 при цистаденокарциномах, серозних та муцинозних цистаденомах порівняно 3 фолікулярними кістами та контролем. Відмінності інтракістозних концентрацій № х в муцинозних, серозних цистаденомах та у фолікулярних кістах були хоча й вірогідними, але невеликими.

Iмуногістохімічне дослідження експресії iNOS показало переважно слабкий їі рівень у фолікулярних кістах і доброякісних цистаденомах, але високий - у цистаденокарциномах

Отже, вплив NO тa iNOS на процеси гіперпроліферації в яєчниках має двоякий характер. Зниження експресії NO та незначна активність iNOS можуть сприяти утворенню кістозних пухлиноподібних та доброякісних пухлинних утворень в яєчниках. Гіперекспресія NO і підвищена активність iNOS пов'язані з процесами малігнізації кістозних утворень епітеліального походження.

Ключові слова: нітрозативний статус, кістозні утворення яєчників неендометріӧдного генезу, N0, iNOS, імуногістохімія.

\section{НИТРОЗАТИВНЫЙ СТАТУС ПРИ ДОБРОКАЧЕСТВЕННЫХ ЭПИТЕЛИАЛЬНЫХ КИСТОЗНЫХ ОПУХОЛЯХ ЯИЧНИКОВ НЕЭНОМЕТРИОИДНОГО ПРОИСХОЖДЕНИЯ}

М.А. Лысенко, аспирант кафедры акушерства и гинекологии № 10 десского НМУ, врач хирургического отделения малоинвазивных методов диагностики и лечения Университетской клиники Одесского НМУ

В.Г. Дубинина, д. мед. н., профессор, зав. кафедрой онкологии с курсом лучевой диагностики, терапии и радиационной медицины Одесского Нму

Е.Н. Носенко, Д. мед. н., профессор кафедры акушерства и гинекологии № 10 десского НМУ

Среди всех опухолей женских половых органов опухоли яичников занимают второе место (6-8\%) по частоте. Доброкачественные формы встречаются в 75-80\% всех настоящих опухолей яичников. Несмотря на достаточно подробную изученность новообразований яичников, причины происхождения их доброкачественных опухолей и кист остаются невыясненными.

Несколько исследований обнаружили важную роль оксида азота (N) в овариальной физиологии. Показано, что яичники локально синтезируют N0, и он может играть роль в процессах развития фолликулов, овуляции и лютеинового формирования. Данные об изменении уровня производных оксида азота и активности синтазы оксида азота (NOS) при доброкачественном опухолевом процессе в яичниках практически отсутствуют.

Целью проведенного исследования стало изучение особенностей нитрозативного статуса при доброкачественных эпителиальных кистозных опухолях яичников неэндометриоидного происхождения. Обследовано 220 пациенток репродуктивного возраста: 40 пациенток с фолликулярными кистами яичников, 60 - с серозными цистаденомами, 60 - смуцинозными цистаденомами, 30 - с цистаденокарциномами неэндометриоидного происхождения, а также 30 пациенток контрольной группы. Исследовано содержание NO в сыворотке крови, интракистозном содержимом, иммунореактивность iNOS в стенках удаленных образований.

Изучение уровней NO в в биологических жидкостях пациенток выявило достоверное снижение содержания сывороточных нейтральных метаболитов NO при цистаденокарциномах, серозной и муцинозной цистаденомах по сравнению с фолликулярной кистой и контролем. Различия интракистозных концентраций № в муцинозной, серозной цистаденомах и в фолликулярной кисте были хотя и достоверными, но небольшими.

Иммуногистохимическое исследование экспрессии iNOS показало преимущественно слабый ее уровень в фолликулярной кисте и доброкачественных цистаденомах, но высокий - в цистаденокарциноме.

Таким образом, Bлияние NO и iNOS на процессы гиперпролиферации в яичниках имеет двоякий характер. Снижение экспрессии NO и незначительная активность iNOS могут способствовать образованию кистозных опухолевидных и доброкачественных опухолевых образований в яичниках. Гиперэкспрессия NO и повышенная активность іNOS связаны с процессами малигнизации кистозных образований эпителиального происхождения.

Ключевые слова: нитрозативный статус, кистозные образования яичников неэндометриоидного генеза, $\mathrm{NO}_{\mathrm{x}^{\prime}}$ NOS, иммуногистохимия. 